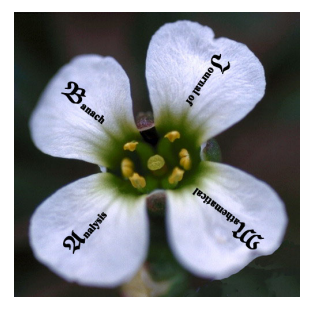

Banach J. Math. Anal. 2 (2008), no. 2, 163-170

B anach Journal of $\mathbf{M}_{\text {athematical }} \mathbf{A}_{\text {nalysis }}$

ISSN: $1735-8787$ (electronic)

http://www.math-analysis.org

\title{
AN INTERVIEW WITH JOSIP E. PEČARIĆ
}

\author{
MOHAMMAD SAL MOSLEHIAN ${ }^{1}$
}

\begin{abstract}
While Professor J.E. Pečarić and the interviewer are meeting each other in three conferences in Iran, Hungary and Croatia, they had some conversations concerning life, ideas and contributions of Professor Pečarić to Mathematics. This paper presents them.
\end{abstract}

\section{INTRODUCTION}

Academician Josip E. Pečarić is the author or co-author of more than 700 scientific articles in mathematics published in mathematical journals, and about 60 mathematical articles are published in books, conference proceedings, or was presented in conferences. He published, in journals or conference proceedings, 20 articles in electrical engineering, geophysics, geology, engineering and physics, and he published, in journals, conferences or as feuilletons 40 articles in history. He is the author or co-author of 16 expert books (6 in English). He is one of the leading world experts in the theory of inequality, so in world reference journals (in USA and Germany) he is called "a great name in the theory of inequality". He is the Editor-in-Chief and founder of the international journal Mathematical Inequalities and Applications, and the Editorial Board consists of about 60 of the most well-known world scientist dealing with the subject. He is a referee for about 60 international journals and several publishing houses. In addition to his scientific work, academician Pečarić is known for his journalistic activities. He is the author or co-author of 250 newspaper articles, and 22 books dealing with journalistic or historical topics.

He is the supervisor for about 30 doctoral theses, some of which are still in making, both in Croatia and internationally. His group is known as Pečarić's group,

Date: Received: July 7, 2008.

2000 Mathematics Subject Classification. Primary 01A99; Secondary 01A60, 01A61.

Key words and phrases. Inequalities; Operator inequalities; Mond-Pečarić method. 
or as Croatian School of the Theory of Inequality. Academician Pečarić cooperates with about 150 mathematicians (from Croatia, USA, Canada, Israel, Great Britain, Sweden, Germany, Austria, Italy, Greece, Romania, Bulgaria, China, Japan, Australia, Singapour, Iran, Pakistan, etc.). Several times he was invited as a visiting professor at the universities in Australia, Italy, Sweden, and participated as plenary speaker in important international conferences. He was awarded with the State Award in Sciences in 1997, and then the President of the Republic of Croatia, Franjo Tudman, decorated him in 1999 with the Order of Danica Hrvatska (Croatian Star) with the effigy of Rudjer Bošković (the highest order for science in Croatia).

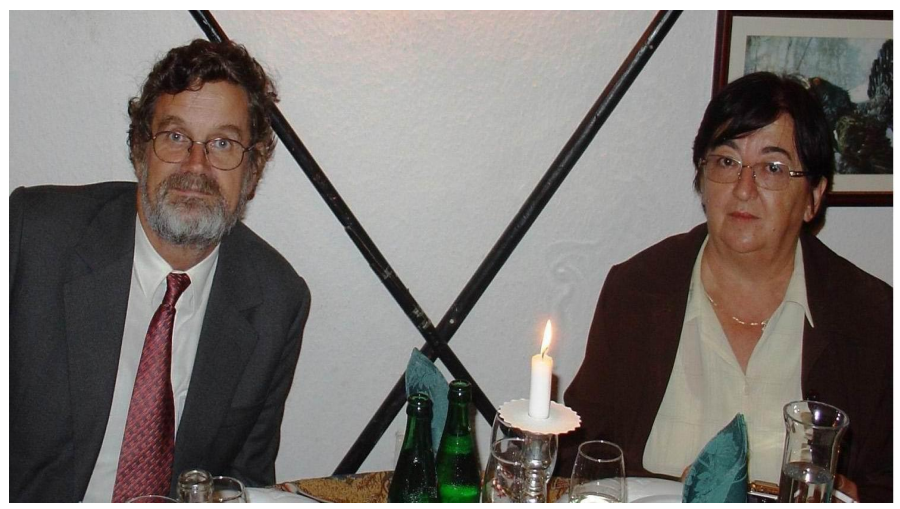

Josip and his wife Ankica Pečarić

\section{INTERVIEW}

- Please tell us about yourself and your education. What made you choose mathematics as the subject of your studies?

* I was born in 1948 in Kotor (Boka Kotorska) where I finished elementary and high school. Then I started studying at the Faculty of Electrical Engineering in Belgrade. One of the professors of mathematics on that faculty was Professor Dragoslav Mitrinović, and most talented mathematicians decided to study at that faculty just because of him. So I also took my master's degree in electrical engineering (my supervisor was also a mathematics professor on that faculty, Professor Dobrilo Tošić), but after that I decided to dedicate myself to pure mathematics. At the time Gradimir Milovanović took his doctoral degree and Professor Tošic gave me a copy of his doctoral thesis, and together with Gradimir Milovanović I wrote my first two articles in 1976. Professor Mitrinović then invited me to work on my doctoral thesis. I finished the work on my thesis by 1979, but I managed to win my degree only in 1982 after a series of attacks on my work. You know that in that time a nationalistic process was beginning to form in Serbia, which later brought to power Slobodan Milošević, who was directly responsible for the war in our region, and I was a Croat in Serbia. In such circumstances one is never directly attacked for what he/she is, but they attacked my work. No matter what, I managed to take my doctoral degree. I couldn't get a position as an assistant professor, although I had more articles than my opposing candidates, so in 1987 
I moved to Zagreb where I was immediately employed as associate professor, and I very soon became full professor.

\section{- What are your honors and awards?}

* I received Annual State Award for Sciences in 1997, and then the President of the Republic of Croatia, Franjo Tudjman, decorated me in 1999 with the Order of Danica Hrvatska (Croatian Star) with the effigy of Ruder Bošković (the highest order for science). I am a full member of the Croatian Academy of Sciences and Arts.

\section{- How did you become interested in inequalities?}

* The first two articles I wrote were on the Ostrowski and Iyengar inequalities, and professor Mitrinović wrote one of the most important monographs in inequalities "Analytic Inequalities, Springer Verlag, 1970". That's why I considered his invitation to work on my doctoral thesis in inequalities as a great privilege. Since my work has been criticized, he let Professor Petar Vasić, whose contribution to inequalities is also very important, to be my supervisor. However, as my cooperation with professor Mitrinović intensified, we wrote many articles and books together. So we have often been described in reference journals as "two great names in the theory of inequality". When I was leaving for Zagreb, he told me: "You should go. It will be better for you there". And in his last letter, dated August 13, 1994, he wrote that "our cooperation has been outstanding".

\section{- Of all of your results which one do you like most? Which one do you think is most important to you?}

* When one has written more than 700 articles, it is difficult to choose one's favorite. Articles are like one's children - you like them all. I have published more than 100 articles on, I believe, the most important inequality, Jensen inequality on convex functions. But if I have to single out some, I will mention the articles on reverse Jensen and Jensen-Stefensen inequalities. From reverse Jensen inequality one gets, as special cases, some classical inequalities like Aczel and Popoviciu. The other is special because it generalized some known results of Petrović's type, and that generalization is much simpler than the results that are generalized. That is very rare in mathematics - usually the generalizations are more complicated. Also my research into Levinson inequality, the analogue to Jensen inequality for 3-convex functions brought me to another inequality of Jensen type. Later it was shown that my inequality can be generalized for n-convex functions, and not only for them, whereas Levinson couldn't. On the other hand, Mond-Pečarić method produced a series of articles, monographs about the method, and a new edition 
of that monograph would be completely different, since many new articles using that method have been published. My first article on Ostrowski inequality is also interesting because that inequality is still being researched and in Zagreb we have arrived at many new interesting results. .

- Many inequalities carry your name: "Milovanović-Pečarić inequality", "Pečarić inequality", "Dedić-Pečarić-Ujević inequality", "LupasBeesack-Pečarić inequality", "Pearce-Pečarić inequality", $\cdots$ and your name is equipped in mathematical analysis with the term "MondPečarić method". Would you briefly explain them for non-experts?

* Mond-Pečarić method deals with matrices and positive linear operators. It is well-known that Jensen inequality is valid for the so-called operator convex functions. We have shown that opposite inequalities in matrices, i.e. positive linear operators, are valid not only for operator convex functions, but for all convex functions. My name is often connected to many inequalities and identities (from which known inequalities are derived) in the literature. It is difficult to write about them all, so I'll just tell you a little story. An author sent his article to J. Math. Anal. Appl. He mentioned Pečarić inequality in the title. Then the Editor-in-Chief of the journal, professor Boas wrote to him that he should change the title of the article: "The title should show what the article is about. And what does 'Pečarić inequality' show when Pečarić has so many inequalities"!

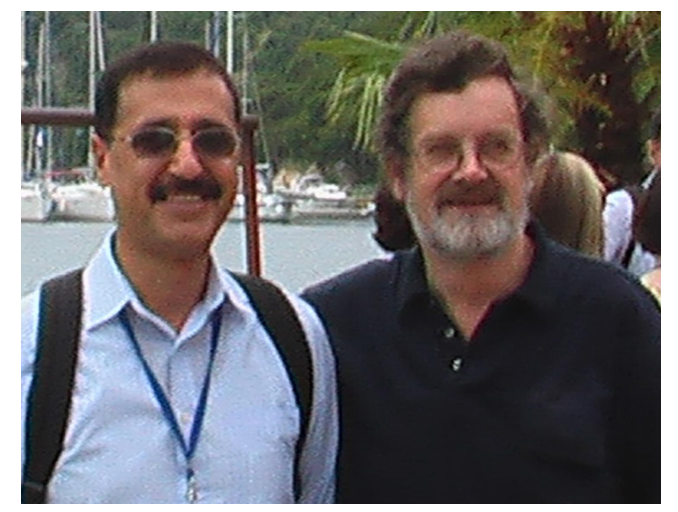

M. S. Moslehian and J. E. Pečarić

- You published more than 700 papers, wrote 16 research books, with many citations to them as MathSciNet shows! With such high level contribution to mathematics what is your feeling?

* I'd like to add that I have started three new mathematical journals: I am the Editor-in-Chief of Mathematical Inequalities and Applications, which has been published for the last ten years and has been cited in SCIE base with a significant impact factor; I am one of the Editors-in-Chief in the journal Operators and Matrices, together with professors Chi-Kwong Li and Leiba X. Rodman, and in 
the Journal of Mathematical Inequalities, together with professor Alois Kufner. I was so glad when I found out that I am exactly the tenth mathematician with more than 500 published articles. It is a nice feeling to be good in something, and especially in mathematics which is, to me, the only aspect of human creative work that is both science and art.

\section{- What is your priority: Teaching or Research?}

$\star$ Research! But I prefer the combination of both, as in the work with graduate students. "My" scientific school in Croatia produced 21 doctors, and more are to take their doctoral degrees soon. I have two doctors in Australia, one in Bosnia and Herzegovina, although formally his supervisor was professor Mitrinović. And I have four doctors in Pakistan.

- Many people think of Mathematics as a difficult subject. Is Mathematics really difficult?

$\star$ First we need to realize that some people are good at logical thinking, while others can memorize a lot of information. The latter surely find mathematics a lot harder than the former. On the other hand there are many among those who are good at logical thinking, but are not good at mathematics simply because mathematics requires continuity and a lot of exercise. Then it is not difficult. In research work one must work a lot, but also needs to have "research nerve".

\section{- What is your opinion about the duality between pure and applied mathematics?}

$\star$ Mathematics is mathematics. If you arrive at new ideas, it is called pure mathematics. The division is caused by the fact that some mathematical disciplines are more expected to bring forth some applications. While in fact, no one can know today what will be applied in future. For those who need mathematics for applications, it is only a tool for their work. We shouldn't be bothered by that. Mathematics is a science in its own right, and we should do our best to make it progress as much as possible. Of course, the trend is such that you will get better research conditions if applications are expected. Scientists from other areas often participate in such research, but they are interested only in the development of those areas of mathematics they can profit from themselves.

\section{- Could you tell us how you work and how do you arrive at new ideas?}

$\star$ It is best to work as much as you can. You can never know when the best idea is going to appear. I would often wake up in the middle of the night because 
I "dreamed" an idea. Or I couldn't fall asleep before I write down what "appeared" in my head. Sometimes you get the right idea simply by studying one and the same article for the thousandth time. To put it simply - there is no rule. You should simply live with the science, and there aren't any "working hours" in science Or there are: 24 hours a day!

\section{- Is Hardy true in saying mathematics is a "young man's game"?}

* I like Hardy's saying, because I'm still good at it. And to be "young" at 60 isn't bad, is it? Seriously, I often wonder myself until when will God give me the ability to create. The longer the better!

\section{- Before you have a proof for something, may you know that it is true?}

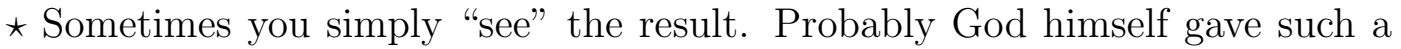
talent to some people. It is not said in vain: not to use the talent God has given is the only unforgivable mortal sin. But I also have opposite experience: I "see" the result, and then prove something else. Once a colleague asked me how I got the generalization of one his identity. I told him that I was convinced that another, different generalization is valid, but that one was the only one I could prove.

\section{- What is the most pleasant aspect of your professional life?}

$\star$ The entire work: so many articles, work with future doctoral candidates and those who have already taken their doctoral thesis, starting of journals, the work in the editorial boards of other journals, citation, monographs (some scientists wrote to me that they consider me their advisor because they started working with the theory of inequality after reading some of my books).

- How can we make mathematics more attractive for young students?

$\star$ As I have already said, the most important thing is to enable young talented mathematicians to continue doing mathematics. Maybe it is a good thing that I study inequalities because they are important for competitions in mathematics. As many of my doctors prepare young students for competitions, through them I help young people choose mathematics as their profession.

\section{- I enjoyed of talking with you.}

$\star$ Me too; and thank you very much for your time and efforts. 


\section{MONOGRAPHS, BOOKS}

1. J. Pečarić, Konveksne funkcije: nejednakosti, Naučna knjiga, Beograd, 1987, 243 pp.

2. D. S. Mitrinović, J. Pečarić, Diferencijalne i integralne nejednadžbe, Naučna knjiga, Beograd, 1988, 168 pp.

3. D. S. Mitrinović, J. Pečarić, and V. Volenec, Recent Advances in Geometric Inequalities, Kluwer Acad. Publ., Dordrecht-Boston-London, 1989, 710 pp.

4. D. S. Mitrinović, J. Pečarić, Srednje vrednosti u matematici, Naučna knjiga, Beograd, 1989, 394 pp.

5. D. S. Mitrinović, J. Pečarić, Monotone funkcije i njihove nejednakosti I, Naučna knjiga, Beograd, 1990, 294 pp.

6. D. S. Mitrinović, J. Pečarić, Hölderova i srodne nejednakosti, Naučna knjiga, Beograd, 1990, 250 pp.

7. D. S. Mitrinović, J. Pečarić, and A.M. Fink, Inequalities Involving Functions and Their Integrals and Derivatives, Kluwer Acad. Publ., Dordrecht-BostonLondon, 1991, 587 pp.

8. D. S. Mitrinović, J. Pečarić, Cikličke nejednakosti i ciklične funkcionalne jednačine, Naučna knjiga, Beograd, 1991, 165 pp.

9. D. S. Mitrinović, J. Pečarić, Nejednakosti i norme, Naučna knjiga, Beograd, 1991, 196 pp.

10. J. Pečarić, F. Prochan and Y.L. Tong, Convex Functions, Partial Orderings, and Statistical Applications, Academic Press, New York-London-TorontoSydney-San Francisco, 1992, 467 pp.

11. D. S. Mitrinović, J. Pečarić, and A.M. Fink, Classical and new Inequalities in Analysis, Kluwer Acad. Publ., Dordrecht-Boston-London, 1993.

12. J. Pečarić, Nejednakosti, Hrvatsko Mat. Društvo i Element, Zagreb 1996.

13. T. Furuta, J. Mićić Hot, J. Pečarić and Y. Seo, Mond-Pečarić Method in Operator Inequalities / Inequalities for bounded selfadjoint operators on a Hilbert space, Element, Zagreb, 2005.

14. L. Larsson, L. Maligranda, J. Pečarić and L.-E. Persson, Multiplicative Inequalities of Carlson Type and Interpolation, World Scientific Publishing Co., Singapore, 2006.

\section{TEXTBOOKS}

15. M. Rekalić, M. Simić, M. Ivanković, J. Pečarić, V. Georgijević, Zbirka zadataka iz fizike, Beograd, 1989, 263 pp.

16. T. Bradić, J. Pečarić, R. Roki i M. Strunje, Matematika za tehnološke fakultete (Mathematics for technology students), 1992; Drugo prošireno izdanje, 1994; Treće izdanje, 1997.

\section{BOOKS FROM HISTORY AND PUBLICISTICS}

17. J. Pečarić, Srpski mit o Jasenovcu / Skrivanje istine o beogradskim konclogorima, Hrvatski povijesni institut, Zagreb, 1998. Drugo izdanje: Srpski mit o Jasenovcu I: Skrivanje istine o beogradskim konc-logorima, Element, Zagreb, 2000. 
18. J. Pečarić, Borba za Boku kotorsku / U Boki kotorskoj svaki kamen govori Hrvatski, Element, Zagreb, 1999.

19. J. Pečarić, Srpski mit o Jasenovcu II /: O Bulajićevoj ideologijigenocida hrvatskih autora, Element, Zagreb, 2000.

20. J. Pečarić, Za hrvatsku Hrvatsku, Element, Zagreb, 2001.

21. J. Pečarić, Serbian myth about Jasenovac, Stih, Zagreb, 2001.

22. J. Pečarić, Sramotni sud u Haagu, Stih, Zagreb, 2001.

23. A. Pečarić and J. Pečarić, Strossmayerova oporuka, HAZU, Zagreb, 2002.

24. J. J. Pečarić, Pronadjena polovica duše / Deset godina s Australskim Hrvatima, Zagreb, 2002.

25. J. Pečarić, Brani li Goldstein NDH? Zagreb, 2002.

26. J. Pečarić, Trijumf tudjmanizma, Zagreb, 2003.

27. J. J. Pečarić, Nepoćudne knjige / Trijumf tudjmanizma 2, Zagreb, 2003.

28. J. Pečarić, Hercegovac iz Boke / Što sam govorio o Hrvatima BiH, Zagreb, 2003.

29. J. Pečarić, U Boki kotorskoj svaki kamen govori hrvatski / Borba za Boku kotorsku 2, Zagreb, 2004.

30. D. Jelčić i J. Pečarić, Tudjmanove tri sekunde, Zagreb, 2004.

Drugo prošireno izdanje, Zagreb, 2007.

31. D. Jelčić i J. Pečarić, Književnik Mile Budak sada i ovdje, Zagreb, 2005.

32. J. Pečarić, Priznajem, Hrvat sam! Zagreb, 2005.

33. D. Jelčić i J. Pečarić, Povijesni prijepori, Zagreb, 2006.

34. M. Pavković, Razgovori s Josipom Pečarićem, Koprivnica, 2006.

35. J. Pečarić, Kad "stručnjaci" odlučuju o matematici, Zagreb, 2006.

36. J. Pečarić, Kako su rušili HAZU?, Zagreb, 2006.

37. J. Pečarić, Za hrvatske vrednote, Zagreb, 2007.

1 Department of Pure Mathematics, Ferdowsi University of Mashhad, P.O. Box 1159, MASHHAD 91775, IRAN.

E-mail address: moslehian@ferdowsi.um.ac.ir and moslehian@ams.org 